УДК 669.136.9: 621.793.6

DOI: $10.31319 / 2519-8106.1(38) 2018.129029$

B.P. Sereda, D.Sc., professor

I.V. Palekhova, engineer

I.V. Kruglyak, $\mathrm{PhD}$, docent

Dneprovsky State Technical University, Kamianske

\title{
USING THE METHOD OF MATHEMATICAL MODELING FOR OBTAINING MULTICOMPONENT TITANIUM SHS-COATINGS
}

The gas transportation SHS-technology of obtaining multicomponent titanium coatings in the mode of thermal self-ignition on iron-carbon alloys is considered. Laws and mechanisms of their formation are investigated. The dependence of the thickness of the coating on the technological parameters of the process (temperature and duration of isothermal aging) has been experimentally established. With the help of methods of mathematical modeling, optimal compositions of SHS-mixtures for the application of complex coatings have been developed. The influence of composition of reaction mixtures on the properties of the obtained coatings is studied. In order to analyze the process of formation of complex coatings on the basis of titanium in the conditions of SHS, the equilibrium state of reaction products in multicomponent powder systems was performed. Proposed kinetic scheme of chemical transformations is proposed. Installed kinetic and thermophysical patterns of growth of coatings.

Keywords: synthesis, coating, mathematical modeling, corrosion resistance.

Розглянуто газотранспортна СВС-технологія отримання багатокомпонентних титанових покриттів в режимі теплового самозаймання на залізо-вуглецевих сплавах. Досліджено закономірності та механізми їх формування. Експериментально встановлено залежність товщини покриттів від технологічних параметрів процесу (температури $i$ тривалості ізотермічної витримки). За допомогою методів математичного моделювання розроблено оптимальні склади СВС-цихт для отримання комплексних покриттів. Вивчено вплив складів СВС-иихт на властивості отриманих покриттів. 3 метою аналізу процесу формування комплексних покриттів на основі титану в умовах СВС виконаний розрахунок рівноважного стану продуктів реакиій в багатокомпонентних порошкових системах. Запропоновано передбачувана кінетична схема хімічних перетворень. Встановлено кінетичні і теплофізичні закономірності росту покриттів.

Ключові слова: синтез, покриття, математичне моделювання, корозійна стійкість.

\section{Formulation of the problem}

In order to improve the reliability of equipment, reduce the cost of its maintenance, increase the service life, titanium-based coatings are widely used. Since in difficult operating conditions onecomponent titanium coatings are not able to provide the necessary working properties of products, it is advisable to saturate the metal surface with several elements. Joint saturation of Ti and Si steels allows not only to increase the hardness of the surface layer, heat resistance and corrosion resistance of products, but also to increase the thickness of applied coatings and accelerate the process of their formation $[1-6]$.

In this paper, the technology of chemical-thermal treatment of steels under self-propagating high-temperature synthesis (SHS) combined with chemical gas-transport reactions is considered [711]. SHS is a high-intensity exothermic interaction of chemical elements in the condensed phase, capable of spontaneous propagation in the form of a combustion wave. Processing processes can be carried out in the mode of combustion or thermal autoignition and are characterized by intensive application of coatings due to the presence of a temperature gradient in the product-powder medium system.

The purpose of this work was the development of powdered SHS-mixtures for the deposition of multicomponent coatings on the basis of titanium in the regime of thermal autoignition, the study of the physicochemical processes of coating formation, the determination of the optimum technological 
parameters of the SHS-process with complex saturation, the study of their influence on the kinetics of layer growth and the evaluation their quality.

\section{Research materials}

Chemical-thermal treatment of carbon steels was carried out in an open-type reactor in the operating temperature range of $950-1100{ }^{\circ} \mathrm{C}$ with an isothermal holding time of $30-60 \mathrm{~min}$. As saturating media, mixtures of chromium and aluminum oxide, titanium, silicon, aluminum and metal iodine (gas transport agent) dispersions of $250-350 \mu \mathrm{m}$ were used.

Surface preparation of the samples included successive stages of grinding, polishing and degreasing in acetone. Initiation of the saturation process was carried out by preheating the resistance in the furnace to the temperature of the start of autoignition (heating rate $0.5^{\circ} \mathrm{C} / \mathrm{s}$ ). The temperatures of the SHS mixture were controlled by a chromel-alumel thermocouple in a protective cover inserted directly into the charge volume and connected to a potentiometer of the PCB series.

The thickness of the strengthened layers was examined with a light microscope "Neophot-21" with an increase of $\mathrm{x} 150, \mathrm{x} 250$. The microstructure was detected by etching in $3 \%$ alcoholic solution of picric acid (TU 6-09-08-317-80). To determine the boundaries of the ferrite grains, a $4 \%$ alcohol solution of nitric acid was used [12].

The elemental composition was investigated by micro-X-ray analysis using the JEOL microprobe "Superprob-733". The localization of the assay is $1 \mu \mathrm{m}^{2}$, the analysis depth is $\sim 1 \mu \mathrm{m}$. The microhardness of the coatings was determined on the PMT-3 device. Corrosion resistance of the samples with coatings was evaluated in a $10 \%$ solution of $\mathrm{H}_{2} \mathrm{SO}_{4}$ at a temperature of $20{ }^{\circ} \mathrm{C}$. To calculate the equilibrium composition of the products of the system, the applied software packages "ASTRA.4" and Recalc were used [13].

When developing compositions of powdered reactive SHS-mixtures providing high corrosion resistance, methods of mathematical design of the experiment were used with the realization of full factorial analysis according to plan $2^{3}$ and fractional factorial experiment $2^{4-1}$.

The choice of the optimum composition of the mixture for conducting SHS-processes in the conditions of thermal autoignition was carried out on the basis of the results of studies of the thermal picture of the SHS process and the physico-mechanical properties of the protective coatings (the corrosion resistance of the coatings was selected as the response function).

Optimization parameters:

Y1 - indicators of corrosion resistance, $\tau_{\mathrm{p} .}-75 \mathrm{~h}$, for the Ti-Si system;

As independent variables, the content of the chromium component in the SHS- mixture, titanium, and silicon was chosen. As a starting material, steel 45 was chosen. The activator of the process is $\mathbf{J}_{2}$ for all systems.

The calculated levels of the variation intervals, the nature of their variations and the coding schemes are presented in Table 1. Introduction of more than $5 \%$ of the gas transport agent into the mixture results in a severe smearing of the sample surface, less than $1 \%$ does not activate the course of all gas transport reactions.

To obtain a $100 \%$ composition of powdered SHS-mixtures, $\mathrm{Al}_{2} \mathrm{O}_{3}$ was used as the final product.

Table 1. Factors studied for the titanium-silicon-chromium system

\begin{tabular}{|l|c|c|c|}
\hline \multirow{2}{*}{ Characteristics } & \multicolumn{3}{|c|}{ Factors } \\
\cline { 2 - 4 } & $\begin{array}{c}\text { In the composition } \\
\text { Ti\%, wt. }\end{array}$ & $\begin{array}{c}\text { In the composition } \\
\text { Si\%, wt. }\end{array}$ & $\begin{array}{c}\text { In the composi- } \\
\text { tion } \\
\text { CC\%, wt. }\end{array}$ \\
\hline Code & $\mathrm{X}_{1}$ & $\mathrm{X}_{2}$ & $\mathrm{X}_{3}$ \\
\hline Basic level & 15 & 10 & 20 \\
\hline Variation interval & 5 & 5 & 5 \\
\hline Lower level & 10 & 5 & 15 \\
\hline Upper level & 20 & 15 & 25 \\
\hline
\end{tabular}


The result of the experiment should be a mathematical relationship between the characteristics studied in the form of a functional connection $y=f(x 1, x 2, x 3, \ldots, x)$.

As a result of the regression analysis, a number of equations were obtained showing the dependence of the corrosion resistance of protective coatings on the regime of thermal autoignition and the content of alloying elements.

Numerical values of the regression coefficients and their significance, determined taking into account the difference in variance for each response function, as well as checking the significance by the Student's criterion and evaluating the adequacy of the model by the Fisher criterion.

To assess the adequacy of the equations, a calculation was made of the regression equations obtained for the optimum regime of thermal autoignition. The results of the calculations were compared with experimental studies.

The results of the research and their discussion

Analysis of the reactions occurring during thermal self-ignition of SHS-charges and the results of metallographic studies of the phase composition of the layers made it possible to determine the scheme for the formation of coatings. The process can be conditionally divided into several stages [14]:

1- inert heating of the reaction mixture to the ignition temperature;

2- thermal autoignition;

3- warming up of products;

4- isothermal aging;

5- cooling.

The production of coatings under conditions of self-propagating high-temperature synthesis occurs under non-stationary conditions, when neither thermal nor chemical equilibrium until the completion of the process and the cooling of the products is possible. The rates of the course of chemical processes are determined by kinetic regularities, which depend both on temperature and on diffusion factors. If we assume that at the stage of heating, the inhibition of diffusion processes in the gaseous phase is small, and the rate of change of temperature is small in comparison with the rate of gas-phase chemical reactions, it can be assumed that the equilibrium composition of the products corresponds to each temperature value. Having calculated the equilibrium composition of reaction products for a number of specific temperatures from the range of its variation, it is possible to follow the development of the SHS process and to suggest the mechanism for the formation of coatings.

The thermodynamic model of the process reduces to the following: the initial mixture consists of $\mathrm{M}$ substances containing 1 chemical elements. For fixed values of volume and temperature, $\mathrm{m}_{\mathrm{k}}$ of substances present in $\mathrm{k}=0,1, \ldots \mathrm{q}$ different phases can be formed from these elements as a result of chemical reactions. The set of substances includes 1 atomic and $(m-1)$ molecular components, the reactions of which are presented in the form of dissociation equations. The mathematical formulation of the problem reduces to minimizing the thermodynamic potential.

Studies show that in the temperature range 300-1800 K, the basic compounds in the gas phase are iodides $\mathrm{TiI}_{4}, \mathrm{Al}_{2} \mathrm{I}_{6}, \mathrm{AlI}_{3}, \mathrm{AlI}_{2}, \mathrm{AlI}, \mathrm{SiI}_{4}, \mathrm{SiI}_{3}, \mathrm{SiI}_{2}, \mathrm{SiI}$ (iodides Ti and Al predominate), as well as iodine in the atomic and molecular form.

The stage of inert heating of the reaction mixture to the ignition temperature is accompanied by the evaporation and decomposition of the gas transport carriers to the atomic state according to the reaction

$$
\mathrm{I}_{2} \Rightarrow 2 \mathrm{I} \text {. }
$$

In the temperature range $300-1800 \mathrm{~K}$ the concentration of gaseous I2 and I continuously increases.

At the stage of thermal autoignition, an exothermic reaction of reduction of chromium oxide

$$
1 / 2 \mathrm{Cr}_{2} \mathrm{O}_{3}+\mathrm{Al} \Rightarrow \mathrm{Cr}+\mathrm{Al}_{2} \mathrm{O}_{3} \text {. }
$$

The temperature in the reactor rises sharply to the maximum process temperature $\mathrm{t}_{\mathrm{m}}$. Gaseous compounds are formed and the main saturating elements are transferred to the substrate by the reaction $\mathrm{M}+\mathrm{m} / \mathrm{n} \mathrm{Gn} \Leftrightarrow \mathrm{MGm}$, where $\mathrm{M}$ is the deposited element, $\mathrm{Gn}$ is halogen, and MGm is the volatile halide. 
It is necessary that the transported element and the substrate are in different temperature zones. At the stage of thermal autoignition, the formation of gaseous iodides Ti, Ai, Si and their chemical transport to the surface of products occurs.

The thermodynamic analysis of the equilibrium composition of the products of the system indicates that in the temperature range under study saturating elements of the reaction mixture interact with iodine both in the atomic and molecular states, however, reactions of interaction of elements with atomic iodine are more probable:

$$
\begin{aligned}
& \mathrm{Al}+\mathrm{I} \Leftrightarrow \mathrm{AlI} ; \\
& \mathrm{Al}+2 \mathrm{I} \Leftrightarrow \mathrm{AlI}_{2} ; \\
& \mathrm{Al}+3 \mathrm{I} \Leftrightarrow \mathrm{AlI}_{3} ; \\
& 2 \mathrm{Al}+\mathrm{I}_{2} \Rightarrow 2 \mathrm{AlI} ; \\
& 2 \mathrm{Al}+\mathrm{AlI}_{3} \Leftrightarrow 3 \mathrm{AlI} ; \\
& 2 / 3 \mathrm{AlI}_{3}+4 / 3 \mathrm{Al} \Leftrightarrow 2 \mathrm{AlI} ; \\
& 2 / 3 \mathrm{AlI}_{3}+1 / 3 \mathrm{Al} \Leftrightarrow \mathrm{AlI}_{2} ; \\
& \mathrm{Al}_{2} \mathrm{I}_{6} \Leftrightarrow 2 \mathrm{AlI}_{3} ; \\
& 1 / 2 \mathrm{Ti}+\mathrm{I}_{2} \Leftrightarrow 1 / 2 \mathrm{TiI}_{4} ; \\
& \mathrm{Ti}+4 \mathrm{I} \Rightarrow \mathrm{TiI}_{4} ; \\
& \mathrm{Si}+2 \mathrm{I} \Leftrightarrow \mathrm{SiI}_{2} ; \\
& \mathrm{Si}+\mathrm{I}_{2} \Leftrightarrow \mathrm{SiI}_{2} ; \\
& \mathrm{Si}+4 \mathrm{I} \Leftrightarrow \mathrm{SiI}_{4} ; \\
& 2 \mathrm{SiI} \\
& \mathrm{Si}
\end{aligned}
$$

At the stage of heating the products, the temperature is equalized over the volume of the reactor and the formation of diffusion active atoms of the elements takes place. When introducing steel products into the powder system, heterogeneous exchange reactions with the iron of the substrate are possible on their surface.

At the stage of isothermal aging the diffusion growth of the coating takes place, the temperature in the reactor does not change.

At the cooling stage, the formation of layers occurs less intensively, which is associated with a decrease in the diffusion coefficients of the saturating elements. At the same time, the cooling rate has a great influence on the quality of the coating.

Coatings obtained in SHS-processes consist of a wide gradient diffusion zone, which therefore have improved characteristics in comparison with diffusion analogues, and are also characterized by high adhesive strength. It is established that the zone of the complex silicide ( $\mathrm{Ti}, \mathrm{Fe})_{5} \mathrm{Si}_{3}$ is formed on the surface of the steels, the zones of aluminides $\mathrm{Fe}_{2} \mathrm{Al}_{5}, \mathrm{FeAl}$, and $\mathrm{Fe}_{3} \mathrm{Al}$ doped with $\mathrm{Ti}$ and $\mathrm{Si}$ are located below it, the zone of the $\alpha$-solid solution of titanium, silicon, aluminum in iron, phase $\mathrm{Ti}_{5} \mathrm{Si}_{3}$.

Conducted tests of SHS-coatings for corrosion resistance showed an increase in this index by $1,5-1,8$ times compared with coatings obtained under isothermal conditions.

\section{Conclusions}

Using the methods of mathematical modeling, compositions of SHS-charges have been developed for obtaining multicomponent titanium coatings on carbon steels. The coatings allowing to increase the corrosion resistance data are obtained in 1,5-1,8 times in comparison with coatings obtained under isothermal conditions.

\section{List of reference links}

1. Химико-термическая обработка металлов и сплавов: Справочник / под ред. Ляховича Л. С. М.: Металлургия, 1981. - 424 с.

2. Ворошнин Л. Г. Антикоррозионные диффузионные покрытия - Минск: Наука и техника, $1981-296 \mathrm{c}$.

3. Лахтин Ю. М., Арзамасов Б. Н. Химико-термическая обработка металлов. Учебное пособие для вузов. - М.: Металлургия, 1985. - 256 с. 
4. Середа Б. П. Поверхневе зміцнення матеріалів: Монографія / Середа Б. П., Калініна Н. С., Кругляк I. В. - Запоріжжя: РВВ ЗДІА, - 2004. - 230 с.

5. Середа Б. П. Металознавство та термічна обробка чорних та кольорових металів. Підручник. - Запоріжжя: Вид-во ЗДІА, 2008. - 302 с.

6. Филоненко Б. А. Комплексные диффузионные покрытия. М.: Машиностроение. $1981-137 \mathrm{c}$.

7. Мержанов А. Г. Процессы горения и синтез материалов.- Черноголовка: ИСМАН, 1998. $512 \mathrm{c}$.

8. Коган Я .Д., Середа Б. П., Штессель Э. А. Высокоинтенсивный способ получения покрытий в условиях СВС / Металловедение и термическая обработка металлов, 1991, № 6.- с. 39-40.

9. Бейгул $О$. О. Отримання зносостійких покриттів на автомобільних деталей при нестаціонарних температурних умовах / Бейгул О. О., Адамчук С. І., Середа Д. Б., Шульга А. С. // Збірник наукових праць ДДТУ, Кам` янське. - 2017. - Випуск 1(30). - С. 77-80.

10.Sereda B., Sereda D. Obtaining of Boride Coatings under SHS Conditions for Car Parts. Material science and technology - 2016. Salt Lake City, Utah USA 2016-1339 p. - P. 945-948.

11.Sereda B., Sereda D. Development of Protective Coatings Formulations Based on Boron for Units Operating at High Temperatures in Metallurgy. Material science and technology 2016. Conference and Exhibition. Salt Lake City, Utah USA 2012-1550 p. - P. 931-934

12.Беккерт M., Клемм X. Справочник по металлографическому травлению. - М.: Металлургия, 1979. $-336 \mathrm{c}$.

13.Синярев Г. Б., Ватолин Н. А., Трусов Б. Г., Моисеев Р. К. Применение ЭВМ для термодинамических расчетов металлургических процессов. - М.: Наука, 1982. -263 с.

14.Середа Б. П., Палехова И. В., Белоконь Ю. А. , Середа Д. Б. Получение интерметаллидных соединений и покрытий при нестационарных температурных условиях. Новые материалы и технологии в металлургии и машиностроении: Научный журнал № 2,2014. ЗНТУ, Запорожье, С. 67-71 